\title{
IMPLEMENTASI PROGRAM BANTUAN PEMERINTAH DALAM UPAYA PENGEMBANGAN WIRAUSAHA PEMULA DI KEMENTERIAN KOPERASI DAN UKM (Studi Pada Kabupaten Lombok Tengah)
}

\author{
Mahendra Purnama Yahya ${ }^{1}$, Bambang Santoso ${ }^{2}$, Alfi Haris Wanto ${ }^{2}$ \\ ${ }^{1}$ Asisten Deputi Permodalan, Kementerian Koperasi dan UKM RI \\ ${ }^{2}$ Universitas Brawijaya, Malang, Jawa Timur, Indonesia \\ Email: mahendrapurnama18@gmail.com
}

\begin{abstract}
This research was motivated by the main problems faced by Small and Medium Enterprises (SMEs) is lack of capital. Refer to Regulations No. 20 of 2008, the Ministry of Cooperatives and SMEs was responsible for empowering SMEs which is through Start-Up Capital Assistances Program for startup Entrepreneur. The aim of the research to analyze and describe the program implementation as well as supporting and inhibiting factors based on the Van Meter and Van Horne policy implementation models. This type of research uses a description method using the qualitative approach. The results show the Implementation of Start-Up Capital Assistances Program for startup Entrepreneur needs to be improved due to lack of communication and and limited resources
\end{abstract}

Keywords: Policy Implementation, Start-up Capital, Small Mediun Enterprise (SMEs)

\begin{abstract}
ABSTRAK
Penelitian ini dilatarbelakangi oleh kendala utama yang dihadapi Usaha Kecil dan Menengah (UKM) adalah masalah permodalan. Berdasarkan Undang-Undang No 20 Tahun 2008, Kementerian Koperasi dan UKM bertugas didalam melakukan pemberdayaan UKM salah satunya melalui Program Bantuan Pemerintah dalam Upaya Pengembangan Wirausaha Pemula.Penelitian ini bertujuan untuk menganalisa serta mendeskripsikan implementesi program serta faktor pendukung \& penghambat berdasarkan model implementasi kebijakan Van Meter dan Van Horne. Jenis penelitian ini merupakan metode deskripsi dengan pendekatan penelitian kualitatif. Hasil dari penelitian ini menunjukkan Implementasi Program perlu ditingkatkan dikarenakan kurangnya komunikasi serta terbatasnya sumberdaya.
\end{abstract}

Keywords: Policy Implementation, Start-up Capital, Small Mediun Enterprise (SMEs) 


\section{PENDAHULUAN}

Usaha Mikro, Kecil dan Menenngah (UMKM) memiliki peran penting dan strateegis dalam pembangunan ekonomi nasional berkelanjutan. Selain berperan dalam petumbuhan ekonomi serta menyerap tenaga kerja, UMKM telah terbukti tidak terpengaruh terhadap krisis ekonomi.

Meskipun secara total UMKM cukup besar dan berkontribusi terhadap PDB Nasional namun Menurut Primiana (2016:98), rasio kewirausahaan masih dibawah negara Asia Tenggara lainnya. Indonesia masih di posisi 3,10\% dari jumlah penduduk Indonesia yang mencapai 264 juta orang. Hingga tahun 2019 pemerintah memiliki target pertumbuhan rasio kewirausahaan sebesar 5\% untuk mengejar ketertinggalan dari Negara Asia Tenggara seperti Malaysia dan Singapura yang mencapai $7 \%$.

Disisi lain, UMKM masih menghadapi berbagai hambatan. Hambatan utama yang sering dialami oleh UMKM adalah keterbatasan akses permodalan atau pembiayaan dari perbankan hal tersebut disebabkan pertama, kendala geografis yaitu masih banyak perbankan yang belum mampu menjangkau hingga daerah pelosook dan terpenciil. Kedua, masalah terkait administratif yaitu sebagian besar UMKM masih dikelolaa secara maanual dengan pembukuan atau manajemen perencanaan keuangan yang masih mengabungkan antara uang operasional rumah tangga dengan usaha. Ketiga, adanya keraguan perbankan yang masih menganggap jaminan yang diberikan oleh UMKM tidak layak jika dibandingkan tingginya resiko yang akan ditanggung oleh perbankan.

Berdasarkan amanat Undang-undang No. 20 Tahun 2008 terkait Usaha Mikro Kecial dan Menengah mengamanatkan pemberdayaan usaaha mikro, kecil dan menengaah dilaksanakan melalui sinergi pemerintah pusat, pemerintah daerah, dunia usaha dan masyarakat secara menyeluruh. Kementerian Koperasi dan UKM sebagai leading sector di dalam pemberdayaan UMKM tertuang di dalam
Rencana Strategis Kementerian Koperasi dan UKM 2015-2019 yaitu meningkatkan wirausaha baru dengan upaya penumbuhan 1 (satu) juta wirausaha pemula secara nasional.

Untuk mencapai target tersebut, maka Kementerian Koperasi dan UKM berusaha mewujudkannya di dalam Program Bantuan Pemerintah dalam Upaya Pengembangan Wirausaha Pemula. Program ini telah dilaksanakan dari tahun 2011, nilai bantuan yang diberikan berkisar 10-13 juta per wirausaha pemula. Sampai Tahun 2017, program ini telah menyalurkan bantuan kepada 18.430 wirausaha pemula, dengan total nilai Bantuan mencapai Rp. 231.500.000.000 yang tersebar di 34 provinsi seluruh Indonesia. Adapun sasaran program wirausaha pemula antara lain: (1) Daerah Terluar, Terdepan, dan Tertinggal (3T); (2) Kawasan Ekonomi Khusus; (3) Kelompok Antar Pendapatan Rendah.

Kabupaten Lombok Tengah sebagai salah satu Kabupaten yang menerima Bantuan Program yang termasuk pada sasaran Kawaasan Ekonomi Khususs (KEK) berdasarkan Peraturan Pemerintah No 52 Tahun 2014. KEK adalah kawasan dengan bataas tertentu dalam wilayah NKRI untuk melaksanakan fungsi perekonomian yang memiliki sifat khusus dan memperoleh fasiliitas tertentu dengan tujuan meningkatkan nilai investasi pada kawasan tersebut.

Selain menjadi salah satu target lokus program, KEK Mandalika mendapat perhatian yang khusus dari Kementerian Koperasi dan UKM di dalam mendukung percepatan pengembangan kawasan seperti fasilitasi pembiayaan, pelatihan, dan pemasaran. Kemudian juga KEK merupakan prioritas dan sasaran pembangunan yaitu pada Dimensi Pembangunan Sektor Unggulan.

Penelitian implementasi program bantuan pemerintah dalam upaya pengembangan wirausaha pemula di Kementerian Koperasi dan UKM didasari pertimbangan bahwa terdapat beberapa fenomena yang mengakibatkan pelaksanaan program tersebut belum berjalan 
secara optimal. Lalu bagaimanakah proses implementasi program bantuan pemerintah dalam upaya pengembangan wirausaha pemula di Kementerian Koperasi dan UKM? Faktorfaktor yang menjadi peendukung dan penghambaat implementasi program tersebut?

\section{KAJIAN PUSTAKA}

\subsection{Teori Implementasi Kebijakan Publik}

Laswell dan Kaplan dikutip oleh Wahab (2008: 78), menjelaskan kebijakan publik sebagai a projecteed program of gooal, value, and practiice atau sesuatu program pencapaian tujuan, dengan nilai-nilai dalam praktekprakteek yang lebih terarah. Hubungan diantara kebijakaan, program dan proyek adalah, suatu kebijakan seringkaali mencakup sejumlah proggram, dan sebuah program terdiri dari sejumlah proyek. Namun, sebuaah kebijakan juga dapat langsung dilakukan dan diimplementasikkan dalam bentuk proyeek. Program-program atau sub-sub programsecara dipandanng sebagai sarana (instrumen) untuk mewujudkan berbagai tujuan-tujuan yang ingin dicapaii oleh kebijakan pemerintah.

\subsection{Teori Implementasi Kebijakan}

Menurut Van Metter dan Van Horn sebagaimana dikutip oleh Nugroho (2017:136). Proses implementasi ini merupakan sebuah abstraksi atau performasi suatu kebijakan yang pada dasarnya secara sengaja dilakukan untuk meraih kinerja implementasi kebijakan yang tinggi yang berlangsung dalam hubungan berbagai variabel. Variabel tersebut adalah: Ukuran Kebijakan; Sumberdaya; Komunikasi organisasii; Karakteristik Agen pelaksana; Sikap para pelaksana serta lingkungan kebijakan seperti yang dapat dilihat pada gambar berikut ini:

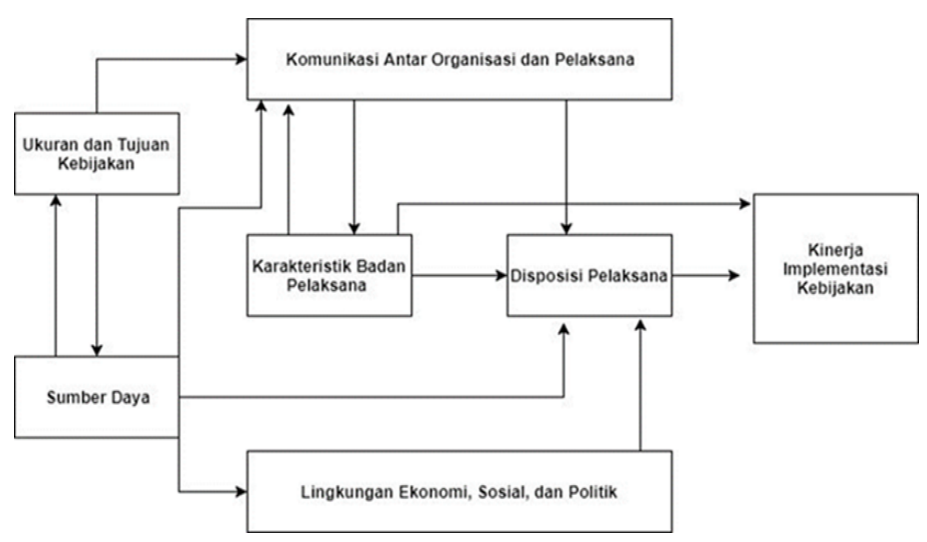

Gambar 1 Implementasi Kebijakan menurut Van Metter dan Van Horn (1975)

\section{METODE PENELITIAN}

Penelitian ini merupakan jenis peneliitian kuaalitatif dengan menggunakan pendekatan analisis deskriiptif.Adapun, Alasan peneliti menggunakan penelitian kualitatif agar mengetahui kejelasan masalah yang akan dibahas. Fokus peenelitian ini adalah untuk mengetahui gammbaran secara keseluruhan tentang seperti apa implementasi program berdasarkan model implementasi keebijakan Van Meter dan Van Hoorn. Serta apa yang menjadi faktor penghambat dan faktor pendukkung dalam implmentasi program.

Pengupulan data dilakukan dengan teknik cara wawancara dengan infoorman, observasi fenomena atau peristiwa, dan menelaah dokumen.

Metode anaalisis yang digunakan dalam penelitian ini merupakan metode analiisis model penelitian kualiitatif yang dikembangkan oleh Ian Dey (1993). Metode ini terdiri dari 5 tahapan yaitu: data collection, describing, classifying, connecting, account.

\section{HASIL PENELITIAN DAN PEMBAHSAN}

Berdasarkan fokus penelitian dikemukakan, dapat dijabarkan pada variabelvariabel yang mempengaruhi Implementasi Program Bantuan Pemerintah Dalam Upaya Pengembangan Wirausaha Pemula menurut model Implmentasi kebijakaan yang dikembangkan oleh Van Meter dan Van Hornn, 
sebagai berikut yaitu: (1) Ukuraan dan Tujun Kebijakan; (2) Sumberdaya; (3) Karateristik Pelaksana; (4) Sikap/Dispossi Agen Pelaksna;(5) Komunikasi Organisasi dan Pelaksana; (6) Lingkungaan Kebijakan serta Faktor Pendukung dan Faktor Penghambat Program.

\subsection{Ukuraan dan Tujuuan Kebijakan}

Ukuran dan Tujuan Kebiijakan, Berdasarkan Petunjuk Teknis Pelaksanan Program Bantuan Pemerintah dalam Upaya Pengembangan Wirausaha Pemula tujuan yang ingn dicapai dari prgram ini adalah dapat menumbhkan wirausaha pemulaa guna mendukungg penciptaan lapangan kerja dan penanggulan kemiskinan, pengurangan kesenjangan pendapatan dan peningkatan penghdupan berkelanjtan. Sasaaran yang menjadi target group program ini adalah Daerah Terdepan, Tertinggal dan Terdepan (3T), Kawasan Ekonomi Khusus dan Kelompok Antar Pendapatan Rendah (KAP). Menurut Van Meter dan Van Horrn sebagaimana dikutip Wiinarno (2014:159) indikator-indikator kinerja merupakan tahapan krusial dalam analasis implementasi kebijakan serta meenilai ukuran-ukuuran dasar dan tujuan kebjakan direalisasikan. Program ini telaah dirasakan manfaatnya oleh para target group yang dapat ditinjau oleh indikator keberhasilan program seperti pertambahan jumlah tenaga kerja sebesar $(50 \%)$, peningkatan total asset usaha (78,8\%), keuntungan bersih (68\%) serta omset usaha $(50,67 \%)$. Selain itu juga berdasarkan hasil penelitian kepada penerima bantuan 2017 dapat diketahui bahwa bantuan yang diberikan bermanfaat untuk dipergunakan membeli kebutuhan usaha seperti bahan baku dan peralatan sehingga output produksi menjadi meningkat. Sementara itu, dari segi pemasaran didampingi oleh dinas terkait telah mampu memasarkan produknya keluar kota bahkan hingga mancanegara. Menurut Grindle sebagaimana dikutip oleh Wahab (2008), menyatakan bahwa tipe manfaat merupakan kebijakan yang telah dibuat meberikan manfat secara kolektiif atau terhadap banyak orag akan lebih mudah untuk memperoleh dukungan dan tingkt kepatuhan yang tinggi dari target groupp/masyaraakat banyak. Indikator dari faktor ini adalah manfaat secaara ekonomi, soosial, dan buddaya yang dapat dirsakan kelommpok sasaran.

\subsection{Sumber Daya}

Sumber Daya; pada penelitian ini dibbedakan menjadi duaa yaitu berupa sumbeer daya manusia dan finansial. Untuk kondisi sumberdaya manusia jumlah karyawan yang dimiliki oleh tim seleksi dan penilai hanya berjumlah 3 (tiga) orang termasuk ketua tim penilaian dan seleksi. Sementara jumlah tim pelaksana internal yang bertugas melakukan verifikasi berkas usulan program hanya berjumlah 5 (lima) orang hal ini masih dirasa sangat terbatas. Oleh karena itu, diperlukan upaya yang ekstra untuk mencapai target yang telah ditentukan mengingat jumlah proposal usaha yang diajukan oleh Dinas Koperasi dan UKM baik di Kabupaten/Kota dan Provinsi jumlahnya bisa melebihi dari target yang ditentukan bahkan mencapai tiga kali lipat.Sementara dari sisi kualitas, Tim Pelaksana internal tidak memiliki kompetensi untuk melakukan penilaian dan seleksi oleh karena itu pengerjaan proses seleksi dan penilaian di serahkan oleh pihak ketiga yaitu tim independen yang ditunjuk oleh Kementerian Koperasi dan UKM. Dari segi sumber daya finasial juga masih dirasa sangat terbatas dikarenakan anggaran fasilitasi program yang merupakan anggaran yang digunakan sebagian besar untuk operasional program ke daerah jumlahnya berkurang dikarenakan adanya kebijakan penghematan anggaran yang dikeluarkan oleh Kementerian Keuangan serta kebijakan internal Kementerian Koperasi dan UKM bahwa anggaran fasilitasi nilainya tidak boleh melebihi $10 \%$ dari total anggaran. Sementara itu Total anggaran dana dan target wirausaha pemula yang disalurkan jumlahnya meningkat jika dibandingkan dengan tahun sebelumnya. Hal ini tentunya akan berdampak terhadap kegiatan ke daerah menjadi kurang optimal. 


\subsection{Karakteristik Agen Pelaksana}

Karakteritik Agen Pelaksana tidak lepas dari 3 aktor utama di dalam implementasi program bantuan dalam upaya pengembangan wirausaha pemula yaitu Kementerian Koperasi dan UKM sebagai leading sector, Dinkope UKM Provinsi serta Dinkope UKM Kabupaten/Kota. Jika ditinjau dari otoritas struktur bersifat top down. Selain 3 aktor utama, program ini juga bersinergi dengan universitas melalui Gerakan Mahasiswa Pengusaha (GMP), Komunitas pengiat UKM, Business Melalui perbankan dan koperasi; serta media dalam sosialisasi program. Hal ini sesuai dengan konsep Penta helix di antara lima aktor atau yang lebih dikenal sebagai konsep ABCGM yaitu: Academician, Business, Community, Government, Media. Model pengembangan sosial Penta Helix mempromosikan budaya inovasi dan sinergi kreatif. Hal ini untuk inovasi sosial dimana para aktor berkumpul dari berbagai sektor masyarakat untuk berbagi tujuan bersama menggunakan keterampilan dan sumberdaya khusus untuk mengatasi berbagai tantangan bersama. (Toncovic, 2017). struktur organisasi dalam hal fragmentasi implementasi program bantuan pemerintah dalam upaya pengembangan wirausaha pemula antara para agen pelaksana telah terjalin koordinasi dan kerjasama yang baik. Hal ini dibuktikan dengan cukup intensnya koordinasi yang dilakukan antara Kementerian Koperasi dan UKM dengan Dinas Koperasi dan UKM di daerah. Standard Operating Prosedure (SOP) tercermin dalam petunjuk pelaksanaan program melalui SK Deputi Bidang Pembiayaan No No: 08/Kep/Dep II/2018. Namun pelaksanaan SOP masih perlu ditingkatkan. Sementara untuk sanksi yang diterapkan masih bersifat administratif.

\subsection{Sikap/Disposisi Agen Pelaksana}

Sikap/Disposisi Agen Pelaksana; Menurut Edwarrd III dalam Winaarno (2005:142-143) mengemukakan "kecenderungan dispossi merupakan salah satu faktor yang mempunyai konsekuensi pentingg bagi implementasi kebjakan yang efektif". Terkait disposisi aktor tercermin dari kecenderungan pada periilaku karyawaan yang patuh terhadaap ataasan. Hal ini dapat tercermin pada komitmen karyawan dalam menyelesaikan pekerjaannya meskipun target pekerjaan terkadang mundur atau diperlukan waktu lembur untuk mencapai target yang diinginkan namun semua pekerjaan dapat terselesaikan. Karyawan yang cenderung bersikap sesuai dengan arahan atasannya. Komitmen yang tinggi dari karyawan ini tentunya akan memberi dampak positif bagi implementasi program. Berdasarkan penyajian data dan pengamatan peneliti dapat diketahui bahwa respon positif implementasi program diberikan oleh semua agen pelaksana hal ini tercermin oleh antusiasme baik dari wirausaha pemula dan dinas kab/kota serta provinsi yang berlomba-lomba untuk mengikuti program ini serta jumlah proposal usulan yang setiap tahunnya mengalami peningkatan. Selain itu juga manfaat program sangat dirasakan oleh Dinas Kabupaten/Kota serta provinsi mulai dari penambahan jumlah tenaga kerja, omset usaha, serta keuntungan bersih.

\subsection{Komunikasi Aktivitas Pelaksana}

Komunikasi Antar Organisasi Pelaksana; Menurut Edward III (1980) Komunikasi dalam implementasi kebijakan mencakup beberapa dimensi penting yaitu transsformasi (transsmisi), kejelaasan informasi (clarity) dan konsistensi informasi (conscistency). Komunikasi program implementasi bantuan pemerintah dalam upaya pengembangan wirausaha pemula di Kementerian Koperasi dan UKM dilakukan secara langsung dan tidak langsung. Komunikasi yang dilakukan secara langsung dapat dilakukan melalui koordinasi, sosialisasi, bimbingan teknis serta Focus Group Discussion (FGD) dengan pihak terkait. Sementara itu, komunikasi tidak langsung merupakan komunikasi dengan memanfaatkan kemajuan teknologi sebagai media sarana komunikasi seperti telepon, SMS, whatsap, email, fax serta website yang dimiliki. Sebagian besar komunikasi program dilakukan melalui komunikasi secara tidak langsung. Komunikasi 
melalui proses transmisi terhadap para pelaksana kebijakan seperti melalui sosialisasi, koordinasi serta bimbingan teknis yang difasilitasi oleh Kementerian Koperasi dan UKM kepada pelaksana program di tingkat daerah.hal ini telah berjalan dengan baik. Namun Komunikasi yang telah terjadi antara Pemerintah Pusat selaku regulator dengan pelaksana kebijakan di tingkat daerah ternyata belum sepenuhnya diteruskan kepada masyarakat penerima kebijakan, dalam hal ini adalah calon penerima bantuan wirausaha pemula. wirausaha pemula dituntut untuk secara mandiri mencari informasi secara mandiri mengenai prosedur program wirausaha pemula. Berdasarkan penelitian yang telah dilakukan Salah satu media yang sebenarnya dapat digunakan sebagai sarana komunikasi program adalah website yang dimiliki Deputi Bidang Pembiayaan yaitu dapat diakses di http://pembiayaan.id namun website ini belum optimal dan konsisten di dalam melakukan update terkait informasi program. Seharusnya website Deputi Bidang Pembiayaan dapat dimanfaatkan sebagai sarana penyampaian informasi yang efektif dikarenakan dapat menjangkau target group secara luas.

\subsection{Lingkungan Kebijakan}

Berdasakan Undang-Undang Nomor 39 Tahun 2009 tentang Kawasan Ekonomi Khusus Pasaal 3 menjelaskan bahwa didalam Kawasan Ekonoomi Khusus (KEK) harus disediakan lokasi usaha, baik sebagai peelaku usaha maupun sebagai pendukkung kegiatan yang berada didalaam KEK. Dengan diberikannya ruang untuk UMKM di Kawasan Ekoonomi Khusus Kaabupaten Lombok Tengah terutama KEK Mandalika, maka banyak bermunculan UMKM - UMKM dalam hal ini adalah wirausaha pemula di Kawasan Ekonomi Khusus, dan UMKM yang berkembang. Dari sisi sosial sebagian besar pelaku usaha berasal dari suku sasak yang secara turun temurun pandai dalam menenun Kondisi sosial ini berdampak terhadap banyaknya pelaku usaha yang bergerak di bidang kerajinan tangan seperti tenun dan kerajinan asli lombok.
Kegigihan dalam melakukan aktivitas usaha lebih di dominasi oleh para pengusaha wanita yang juga mendukung di sektor pariwisata. Meskipun beberapa waktu lalu Lombok dilanda bencana gempa, namun sebagian besar daerah yang terdampak adalah Kabupaten Lombok Utara.Sedangkan untuk Kabupaten Lombok Tengah dampak gempa tidak terlalu mempengaruhi aktivitas perekonomian UKM. Publik dalam hal ini penerima program memberikan respon positif terhadap program wirausaha pemula. Hal ini tercermin dari antusiame yang tinggi terhadap program ini untuk mendapatkan program ini kembali di tahun-tahun selanjutnya. Selain itu juga publik sangat merasakan manfat dari program dikarenakan adanya peningkatan omset penjualan dan dapat mengembangkan usahanya dengan bantuan modal yang telah diberikan. Sementara itu dari sisi politik masih ditemukan elit-elit politik yang mempengaruhi implementasi program dengan memperjuangkan konstituennya untuk juga mendapatkan program wirausaha pemula terutama pada daerah-daerah tertinggal dan terluar yang juga menjadi sasaran program. Kementerian Koperasi dan UKM sebagai leading sector program berusaha untuk bersifat netral dan mengakomodir apa yang menjadi tuntutan atau permintaan elit politik dengan syarat harus sesuai dengan petunjuk teknis pelaksanaan program.

\subsection{Faktor Pendukung dan Penghambat implementasi program}

Faktor pendukung Program Bantuan Pemerintah dalam Upaya Pengembangan Wirausaha Pemula di Kementerian Koperasi dan UKM yaitu: (1) Pesatnya perkembangan teknologi sebagai sarana komunikasi program; (2) Komitmen para pelaksana program; (3) Dukungan dan antusiasme publik terhadap program; (4) adanya petunjuk teknis pelaksanaan program. Sementara faktor penghambat program yaitu: (1) belum optimalnya komunikasi dan koordinasi program; (2) terbatasnya sumberdaya pelaksana program dan sumberdaya finansial; (3) Belum 
adanya standarisasi proposal usaha; (4) kurangnya kesadaran penerima program untuk melaporkan perkembangan usaha/monitoring dan evaluasi serta (5) masih terdapat retur berkas pencairan program

\section{KESIMPULAN DAN SARAN}

Implemetasi Program Bantuan Pemerintah Dalam Upaya Pengembangan Wirausaha Pemula di Kementerian Koperasi dan UKM masih perlu ditingkatkan hal tersebut di dasarkan pada variabel sebagai berikut:

a. Ukuraan dan Tujuan Kebijakan. Pemahaman agen pelaksana baik pusat maupun daerah terkait ukuraan dan tujuan program sudah baik sekali dan seesuai dengan apa yang sudah diatur didalam Petunjuk Teknis Pelaksanaan. Selain itu manfaat program juga sangat dirasakan oleh para penerima program (Beneficiaries) yang tercermin di dalam indikator keberhasilan program.

b. Sumberdaya; Dukungan sumberdaya dalam Implementasi Program Bantuan Pemerintah dalam Upaya Pengembangan Wirausaha Pemula di Kementerian Koperasi dan UKM, baik dari sumberdaya manusia maupun sumberdaya finansial belum mencukupi

c. Karakteristik Agen Pelaksana; Karakteristik organisasi berhubungan dengan struktur organiasasi serta fragmentasi. Model kebijakan yang terdapat pada program ini adalah model top-down hal ini tercermin dari pembuatan kebijakan yang terpusat di Kementerian Koperasi dan UKM sementara Dinas Koperasi dan UKM merupakan pelaksana kebijakan. Masingmasing pelaksana sudah mengetahui tugas dan fungsinya masing-masing. Dari sisi SOP, Program sudah memiliki SOP yang jelas namun pada implementasinya masih dirasa belum optimal. Sementara sanksi program masih bersifat administratif

d. Sikap/Disposisi Para Pelaksana; Respon positif implementasi program diberikan oleh semua agen pelaksana hal ini tercermin oleh antusiasme baik dari wirausaha pemula dan dinas kab/kota serta provinsi untuk mengikuti program ini. Selain itu juga manfaat program sangat dirasakan oleh Dinas Kabupaten/Kota serta provinsi.

e. Komunikasi Antar Organisasidan Aktivitas Pelaksana; Komunikasi program dilakukan melalui komunikasi langsung maupun tidak langsung. Namun sebagian besar komunikasi program dilakukan secara tidak langsung. informasi mengenai program belum secara optimal ditransmisikan secara langsung kepada masyarakat/calon wirausaha pemula sebagai penerima kebijakan sebagai contoh sebagai website deputi bidang pembiayaan yang merupakan salah satu sarana komunikasi dan sosialisasi yang efektif belum dilakukan update terkait deadline program serta website tersebut masih kurang diketahui oleh masyarakat luas. Kejelasan tujuan dan standar komunikasi antara regulator dengan pelaksana program sudah tercapai. Namun konsistensi dan keseragaman penyampaian informasi kepada pihak eksternal belum dioptimalkan.

f. lingkungan kebijakan yang terdiri dari sosial ekonomi, opini publik serta dukungan elit politik memiliki respon yang positif/ mendukung program wirausaha pemula. Sejauh dilaksanakan program belum ada penolakan-penolakan terhadap program wirausaha pemula.

g. Faktor pendukung Program Bantuan Pemerintah dalam Upaya Pengembangan Wirausaha Pemula di Kementerian Koperasi dan UKM yaitu : (1) Pesatnya perkembangan teknologi sebagai sarana komunikasi program; (2) Komitmen para pelaksana program; (3) Dukungan dan antusiasme publik terhadap program; (4) adanya petunjuk teknis pelaksanaan program 
h. faktor penghambat program yaitu: (1) belum optimalnya komunikasi dan koordinasi program; (2) terbatasnya sumberdaya pelaksana program dan sumberdaya finansial; (3) Belum adanya standarisasi proposal usaha; (4) kurangnya kesadaran penerima program untuk melaporkan perkembangan usaha/monitoring dan evaluasi serta (5) masih terdapat retur berkas pencairan program

\section{DAFTAR PUSTAKA}

Agustino, Leo. 2006. Politik dan Kebijakan Publik. Bandung: IAPI .

Abdul Wahab, Solichin, 2008. Analisis Kebijakan Dari Formulasi ke Implementasi Kebijaksanaan Negara. Jakarta: Bumi Aksara.

Dey,Ian 1993. Qualitative Data Analysis. London: Routledge

Edwards III, George C, 1980. Implementing Public Policy. Washington DC: Congressional Quartely.

Meter Van D. S., and C. E. Van Horn, 1978. The Policy Implementation Process: A Conceptual Framework, Administration and Society. New Jersey: Foresman and Company.

Nawawi, Ismail.2009.Public Policy Analisis Strategi Advokasi Teori dan Praktek. Surabaya: PMN

Primiana, Ina. 2016. Menggerakkan Sektor Riil UKM \& Industri.. Bandung: Alfabeta

Subarsono, Drs. AG. 2008. Analisis Kebijakan Publik: Konsep, Teori, dan Aplikasi. Yogyakarta:Pustaka Pelajar

Sugiyono, Prof. Dr., 2015. Metode Penelitian Manajemen. Bandung:Penerbit Alfabeta

Tonkovic, A.M, Veckie, E, 2015. Aplications of Penta Helix Model in Economic Development.Economy of eastern croatia yesterday, today, tomorrow, 4.385-393

Undang-Undang Republik Indonesia Nomor 20 Tahun 2008 tentang Usaha Kecil dan Menengah.
Winarno, Budi, 2014.. Teori dan Proses Kebijakan Publik. Yogyakarta: Media Pressindo. 